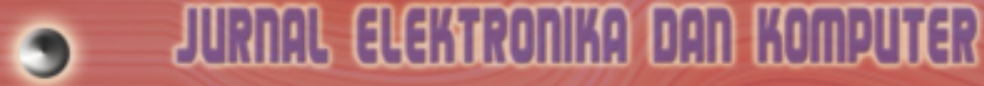

Analisis Pemakaian Sensor Loadcell Dalam Perhitungan Berat Benda Padat dan Cair Agus Wibowo Agus Wibowo

Rancang Bangun Sistem Keamanan Sepeda Motor Menggunakan Rfid dan Personal Identification Number (Pin) Berbasis Mikrokontroler Atmega16

Galang Yudha Murih Raharja, Padjar Setyobudi

Sistem Pencegah Kebakaran Pada Perkebunan Jambu Biji Menggunakan Sensor Suhu Lm35 dan Sms Gateway Berbasis Arduino Uno Kelik Bayu Susatyo

Jurnal ELKOM diterbitkan oleh Sekolah Tinggi Elektronika dan Komputer (STEKOM). Jurnal ELKOM sebagai sarana komunikasi dan penyebarluasan hasil penelitian, pemikiran serta pengabdian pada masyarakat

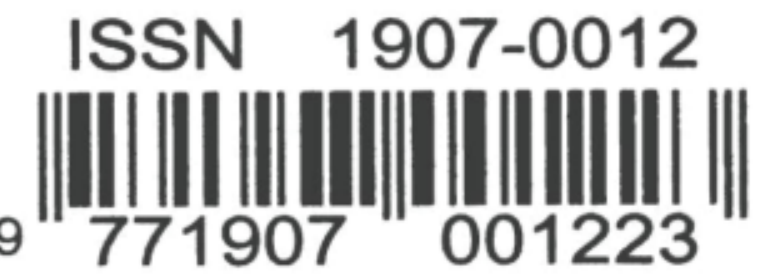

STEKOM

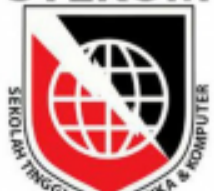
Sekolah Tinggi Elektronika dan Komputer SEMARANG 


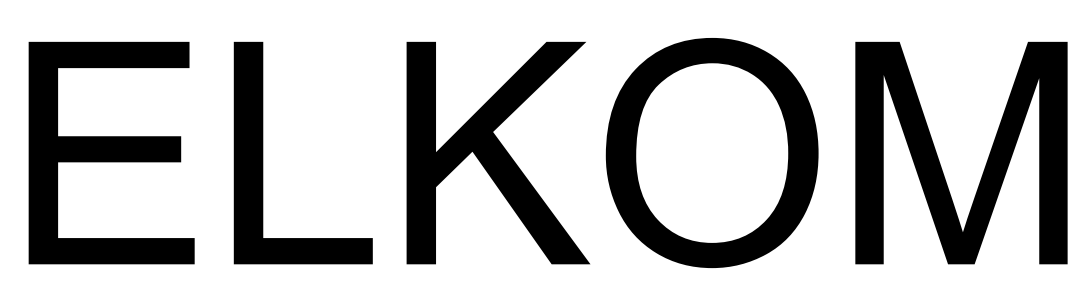

JURNAL ELEKTRONIKA DAN KOMPUTER

Penanggung Jawab :

Ketua Sekolah Tinggi Elektronika \& Komputer

Pemimpin Redaksi :

Sulartopo, S.Pd, M.Kom

Penyunting Pelaksana :

Dr. Ir. Drs. R. Hadi Prayitno, S.E, M.Pd

Dr. Ir. Agus Wibowo, M.Kom, M.Si, M.M

Sarwo Nugroho, S.Kom, M.Kom

Sekretaris Penyunting:

Ir. Paulus Hartanto, M.Kom

Mars Caroline Wibowo, S.T, MT. Tech

Sekretariat :

Dr. Unang Achlison, S.T, M.Kom

Djoko Soerjanto, S.E, M.Kom

Muhammad Sidik, S.Kom, M.Kom

Desain Grafis :

Setiyo Adi Nugroho,S.E, S.Kom

Alamat Redaksi :

Pusat Penelitian - Sekolah Tinggi Elektronika \& Komputer (STEKOM) Jl. Majapahit No. 605 Semarang Telp. 024-6710144 E-Mail :

elkom@stekom.ac.id 


\section{KATA PENGANTAR}

Puji syukur ke hadirat Tuhan Yang Maha Esa dengan terbitnya Jurnal elektronika dan computer (ELKOM) Edisi Maret 2019, Volume 12 Nomor 1 Tahun 2019 dengan artikel-artikel yang selalu mengikuti perkembangan IImu Pengetahuan dan Teknologi dalam bidang elektronika dan computer. Semua artikel yang dimuat pada Jurnal elektronika dan komputer (ELKOM) ini telah ditelaah oleh Dewan Redaksi yang mempunyai kompetensi di bidang elektronika dan komputer. Pada edisi ini kami menyajikan beberapa topik menarik tentang penerapan elektronika dan komputer yaitu: "Analisis Pemakaian Sensor Loadcell Dalam Perhitungan Berat Benda Padat dan Cair Berbasis Microcontroller", serta "Rancang Bangun Sistem Keamanan Sepeda Motor Menggunakan RFID dan Personal Identification Number (Pin) Berbasis Mikrokontroler Atmega16", selanjutnya "Sistem Pencegah Kebakaran Pada Perkebunan Jambu Biji Menggunakan Sensor Suhu LM35 dan SMS Gateway Berbasis Arduino Uno ", dan "Sistem Pengendalian Suhu Air Nutrisi Hidroponik Nft (Nutrient Film Tehnique) Menggunakan Sensor Suhu Dan Sms Gateway Berbasis Arduino (Studi Kasus Di Siliwangi Indah Hidroponik)". Terima kasih yang mendalam disampaikan kepada penulis makalah yang telah berkontribusi pada penerbitan Jurnal ELKOM edisi kali ini. Dengan rendah hati dan segala hormat, mengundang Dosen dan rekan sejawat peneliti dalam bidang elektronika dan komputer untuk mengirimkan naskah, review, gagasan dan opini untuk disajikan pada Jurnal elektronika dan komputer (ELKOM) ini. Sebagai akhir kata, saran dan kritik terhadap Jurnal elektronika dan komputer

(ELKOM) yang membangun sangat diharapkan. Selamat membaca.

Semarang, Maret 2019 


\section{DAFTAR ISI}

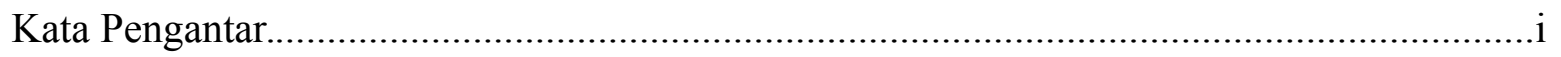

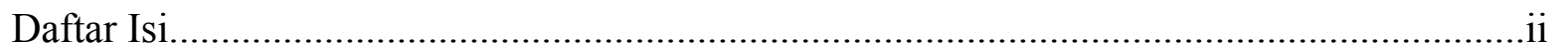

1 Analisis Pemakaian Sensor Loadcell Dalam Perhitungan Berat Benda Padat dan Cair Berbasis Microcontroller, Agus Wibowo...................................... $1-5$

2 Rancang Bangun Sistem Keamanan Sepeda Motor Menggunakan RFID dan Personal Identification Number (Pin) Berbasis Mikrokontroler Atmega16, Galang Yudha Murih Raharja ,Padjar Setyobudi

3 Sistem Pencegah Kebakaran Pada Perkebunan Jambu Biji Menggunakan Sensor Suhu LM35 dan SMS Gateway Berbasis Arduino Uno, Kelik Bayu Susatyo

4 Sistem Pengendalian Suhu Air Nutrisi Hidroponik Nft (Nutrient Film Tehnique) Menggunakan Sensor Suhu Dan Sms Gateway Berbasis Arduino (Studi Kasus Di Siliwangi Indah Hidroponik), Nurul Khabib Allin 


\title{
SISTEM PENCEGAH KEBAKARAN PADA PERKEBUNAN JAMBU BIJI MENGGUNAKAN SENSOR SUHU LM35 DAN SMS GATEWAY BERBASIS ARDUINO UNO
}

\author{
Kelik Bayu Susatyo \\ Program Studi Sistem Komputer \\ Sekolah Tinggi Elektronika dan Komputer \\ Email : radenkelikbayu@gmail.com
}

\begin{abstract}
ABSTRAK
Jambu Biji merupakan tanaman buah dengan berbagai manfaat untuk manusia. Baik daun maupun buahnya dapat digunakan untuk mengobati berbagai macam penyakit. Seperti contoh buahnya untuk mengobati penyakit Demam Berdarah Dengue, Tyfus, dan lain sebagainya. Untuk daunnya dapat digunakan sebagai obat tradisional untuk mengobati penyakit batuk dan diare.

Di dataran tinggi memang udara dingin dan kemungkinan kecil terjadi kebakaran perkebunan. Akan tetapi kebakaran dapat terjadi akibat ulah manusia baik disengaja maupun tidak segaja. Letak lahan perkebunan yang relatif jauh dari perumahan penduduk membuat kebakaran terkadang terlambat diketahui.Oleh karena itu perlu diciptakan alat untuk memantau keadaan suhu maupun kepekatan asap perkebunan jambu biji dari jarak jauh setiap harinya sehingga jika suhu atau kepekatan asap mencapai angka tertentu yang menandakan terjadinya kebakaran maka alat akan langsung mengirimkan pemberitahuan melalui SMS kepada pemilik perkebunan. Selain itu alat akan langsung menyiramkan air dari tandon atau bak penampungan air menuju lahan perkebunan jambu biji. Di dalam bak penampungan air terdapat alat untuk mendeteksi volume air. Alat yang akan diciptakan ini menggunakan sensor suhu LM35, sensor asap MQ-2, sensor Ultrasonik HC-SR04, Relay, mikrokontroler Arduino Uno R3 dan GPRS Shield besertaGSMSIM Card.
\end{abstract}

Kata Kunci: Arduino, LM35, MQ-2, SMS Gateway, Sensor Ultrasonik HC-SR04.

\section{PENDAHULUAN}

Api merupakan bagian penting dalam kehidupan manusia. Seperti contohnya api dapat digunakan untuk memasak makanan, membakar batu bata sebagai bahan untuk membuat dinding bangunan rumah yang kokoh, hingga digunakan untuk menyuling tanaman yang nantinya menjadi minyak esensial yang bermanfaat untuk kehidupan manusia. Ini adalah sisi positif api bagi kehidupan manusia.

Sisi lain dari api adalah negatif yaitu dapat mengakibatkan kebakaran hutan, perkebunan maupun rumah. Di berbagi tempat di belahan dunia manapun dan di negara manapun pasti tidak asing lagi dengan terjadinya kebakaran baik itu kebakaran kecil, sedang maupun besar. Penyebabnya bisa bermacam-macam namun umumnya bersumber dari faktor manusia, faktor teknis, faktor alam dan bencana alam.

Berdasarkan pengalaman pribadi orang tua penulis yang memiliki tanah lahan yang ditanami pohon jabon di Kampung Delok RT02/RW03, Kelurahan Polaman, Kecamatan Mijen, Kota Semarang sebagai usaha bisnis. Setelah sekitar tiga tahun pohon-pohon itu tumbuh subur hingga mencapai tinggi sekitar 5 meter. Oleh karena posisi lahan yang berada di desa lain dan jauh dari rumah penulis serta jauh dari rumah penduduk maka tidak setiap hari ayah penulis memeriksa, oleh karenanya perawatan dipercayakan kepada seorang 
pekerja yang dipilih untuk menjaga lahan.

Kebakaran terjadi dua kali di wilayah yang sama. Pertama di lahan ini terjadi bulan Juli 2012. Awal mulanya karena ada seseorang yang berniat untuk membakar semak-semak dan rerumputan kering di lahan miliknya sendiri lambat laun apinya menyebar di lahan sekitar yang tentunya milik orang lain. Akhirnya api itu menyebar juga pada lahan milik orang tua penulis. Tanaman-tanaman yang mulanya tumbuh subur akhirnya terbakar. Kerugian yang diakibatkan oleh kebakaran ini mencapai puluhan juta. Tidak hanya itu untuk merawat tanamantanaman dibutuhkan juga pengorbanan tenaga dan waktu. Namun karena pelaku penyebab kebakaran ini adalah orang yang sudah lanjut usia maka kerugian tidak diganti. Rupiah yang telah dikeluarkan sirna begitu saja.

Kebakaran kedua terjadi pada akhir bulan Agustus 2014 namun yang kedua kalinya ini berupa tanaman pisang. Meskipun kerugian materi tidak terlalu besar namun terdapat kerugian lainnya berupa pengorbanan tenaga dan waktu. Pelaku penyebab terjadinya kebakaran yang kedua ini adalah orang yang berbeda dengan alasan yang hampir sama.

Dari pengalaman tersebut dapat diketahui bahwa kebakaran dapat terjadi di tempat yang dianggap kemungkinan kecil terjadi kebakaran. Akan tetapi pada kenyataannya kebakaran dapat terjadi dengan berbagai alasan beberapa di antaranya telah disebutkan. Dengan permasalahan yang ada penulis ingin meneliti dan mengembangkan alat yang dapat mengantisipasi terjadinya kebakaran di perkebunan jambu biji milik Kelompok Tani Cepoko Mulyo, Cepoko, Gunungpati, Semarang berupa sistem

pencegah antisipasi kebakaran menggunakan sensor suhu LM35 dan SMS Gateway berbasis Arduino Uno yaitu alat yang dapat menginformasikan keadaan suhu pada lahan perkebunan jambu biji. Dengan demikian dapat mengantisipasi dan meminimalkan terjadinya kebakaran sekala besar.

\section{METODOLOGI PENELITIAN}

Langkah- langkahpenulisdalam membangun suatu sistem pencegah kebakaran pada perkebunan jambu biji menggunakan sensor suhu LM35 dan SMS Gateway berbasis Arduino Uno menggunakan metode Research and Development (R\&D).

Langkah- langkah penggunaan metode R\&D :

a. Potensi dan Masalah, potensi adalah segala sesuatu yang bila didayagunakan akan memiliki nilai tambah. Masalah jika dapat didayagunakan akan menjadi suatu potensi, sebaliknya semua potensi akan berkembang menjadi masalah bila tidak dapat didayagunakan.

b. Mengumpulkan Informasi, informasi dapat diperoleh dan dikumpulkan dari obervasi, Interview, dan Studi Literatur.

c. Desain Produk, dalam penelitian di Kelompok Tani Cepoko Mulyo, Cepoko, Gunungpati, Semarang, untuk pembuatan web menggunakan bahasa PHP dan pemrograman Arduino menggunakan Bahasa $\mathrm{C}$.

d. Validasi Desain, validasi desain merupakan salah satu proses pengujian yang dilakukan guna mengetahui tingkat kebenaran menggunakan angket. Setelahnya validasi desain akan mencakup tentang pernyataan yang ada kaitanya dengan sistem informasi kebakaran dan akan divalidasi oleh pakar dan user.

e. Perbaikan Desain, pada tahap ini seorang pakar melakukan uji validasi dari desain yang dihasilkan. Bila tidak sesuai dengan yang diharapkan maka 
peneliti akan melakukan perbaikan atau merevisi sesuai yang diminta oleh pakar.

f. Uji Coba Produk, pada tahap ini fokus pembahasan ada pada keefektivan alat mengenai kebakaran dan penangannya. Jika model evaluasi beserta instrumen ternyata belum memenuhi syarat pengujian akan dilakukan perbaikan dan diuji coba lagi. Ujicoba dan perbaikan ini akan dilakukan berulang hingga diperoleh prototype akhir yang memenuhi syarat.

\section{HASIL DAN PEMBAHASAN}

\begin{abstract}
Sistem pencegah kebakaran pada perkebunan jambu biji menggunakan sensor suhu LM35 dan SMS Gateway berbasis Arduino Uno. Pada produk yang dikembangkan ini dengan membuat suatu sistem yang berfungsi untuk mempermudah dan memberkan informasi mengenai kondisi perkebunan jambu biji. Alat utama

tidak boleh terkena air akrena akan merusak berbagai komponen di dalamnya. Alat utama dapat diletakkan di dalam panel box yang terpasang di sekitar area perkebunan atau juga dapat dipasang di dalam gubug maupun rumah kecil yang sengaja dibuat untuk

menempatkan alat tersebut. Pada alat menampilkan suhu maupun kepekatan asap sehingga apabila terjadi suhu memanas hingga 40 。C ke atas dan atau kepekatan asap mencapai 200 ppm ke atas maka sistem akan menyalakan pompa untuk menyirami area tersebut. Tidak hanya itu sistem juga akan
\end{abstract}

melakukan pemberitahuan melalui SMS Gateway sehingga nomor telepon seluler yang terdaftar pada sistem akan mendapatkan pemberitahuan. Jika suhu terdeteksi mencapai 50 。C ke atas dan atau kepekatan asap mencapai $250 \mathrm{ppm}$ ke atas maka sistem akan melakukan panggilan kepada nomor telepon yang sudah terdaftar pada sistem. Semua data mengenai gejala kebakaran dikirim ke basis data dalam web.

\subsection{Skema Rangkaian Sistem}

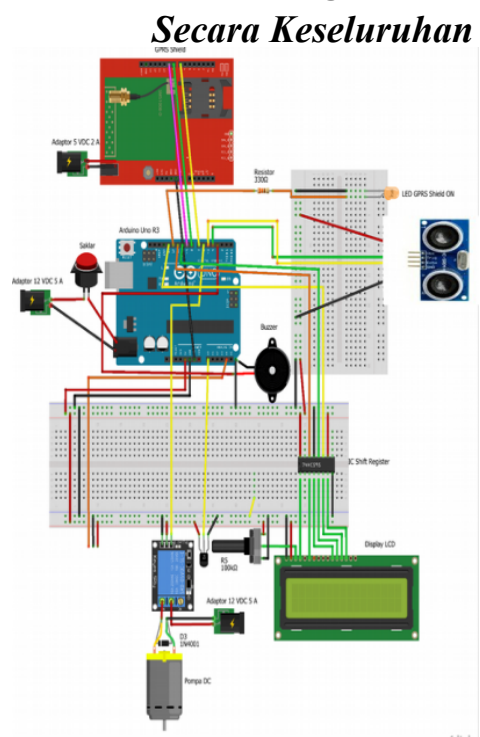

Gambar 1.Skematik rangkaian sistem keseluruhan pada Fritzing

Dari skematik rangkaian sistem di atas adapun keterangannya sebagai berikut :

a. Adaptor sebagai sumber daya untuk menghidupi

Arduino Uno R3, GPRS Shield dan Pompa DC.

b. Saklar untuk menyambung dan memutus aliran listrik.

c. Arduino Uno R3 sebagai papan board utama atau pengendali dari segala perintah dan proses kerja dari keseluruhan sistem.

d. GPRS Shield sebagai perangkat untuk melakukan SMS Gateway maupun Telephony Gateway.

e. Relay menjadi penghubung antara Arduino Uno R3 dan Pompa DC. 
f. Pompa DC berfungsi untuk menyiramkan air pada perkebunan jambu biji.

g. Sensor HC-SR04 merupakan sensor jarak ultrasonik.

h. Sensor LM35 merupakan sensor suhu.

i. Sensor MQ-2 untuk mendeteksi kepekatan asap diukur menggunakan satuan ppm.

j. Modul LCD $16 \times 2$ sebagai penampil nilai suhu dan kepekatan asap.

k. Alarm sebagai peringatan untuk jarak dekat.

1. LED berfungsi sebagai indikator bahwa GPRS Shield terhubung dengan jaringan.

\subsection{Diagram Alur Kerja Sistem}

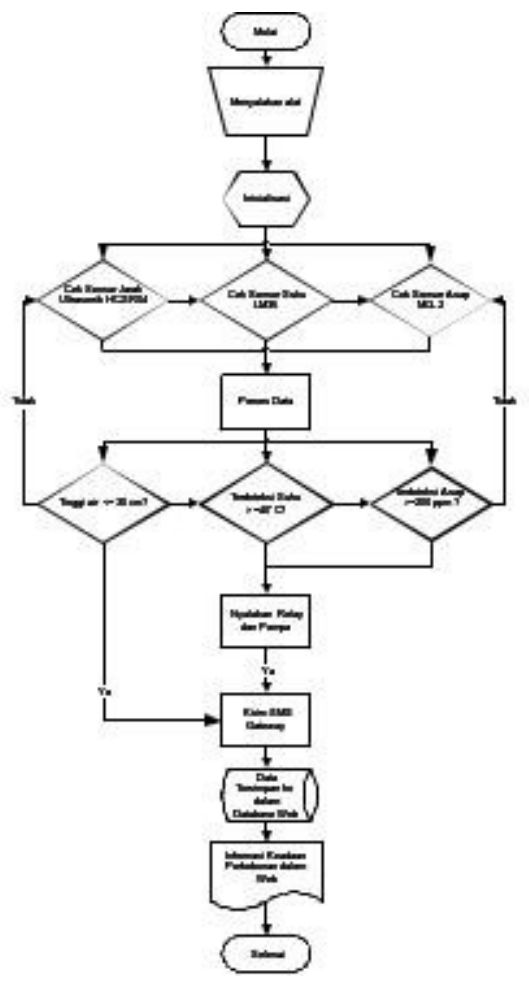

Gambar 2Diagram alir rangkaian

sistem keseluruhan.

Adapaun cara kerja keseluruhan rangkaian sistem di atas diawali dengan menyalakan alat dengan cara menekan tombol ON pada saklar. Saat tombol ON listrik yang mengalir dari adaptor akan mengalir menuju papan rangkaian Arduino Uno R3. Setelah Arduino Uno R3 dinyalakan sistem secara otomatis akan menyalakan GPRS Shield. Sistem akan mengaktifkan sensor Jarak Ultrasonik HC-SR04, LM35 dan sensor asap MQ-2 untuk mendeteksi ukuran air dalam bak, suhu dan kepekatan asap pada lingkungan. Jika tinggi air kurang dari $30 \mathrm{~cm}$ maka sistem akan mengirim pesan ke telepon pengguna. Jika suhu mencapai $40 \circ \mathrm{C}$ ke atas maka alarm dinyalakan sistem lalu memerintahkan relay sebagai saklar untuk menyalakan pompa DC agar dapat mengalirkan air menuju tanaman. Sistem memerintahkan GPRS Shield untuk mengirimkan pesan dengan kalimat "Suhu terdeteksi mencapai $40 * \mathrm{C}$ ke atas" menuju nomor ponsel yang telah didaftarkan pada sistem. Jika suhu belum turun dan suhu bertambah maka nilai yang terbaca oleh sensor suhu juga ikut naik. Jika telah mencapai 50 。C ke atas pompa DC masih menyala, alarm juga masih menyala tetapi kali ini GPRS Shield akan melakukan panggilan kepada nomor ponsel tersebut. Ketika suhu menurun dan berada di bawah 40。C alarm akan dimatikan selain itu

sistem memerintahkan relay memutus aliran listrik dari adaptor menuju pompa DC.

Jika kepekatan asap mencapai 200 ppm ke atas maka sensor akan menyalakan alarm dinyalakan sistem lalu memerintahkan relay sebagai saklar untuk menyalakan pompa DC agar dapat mengalirkan air menuju tanaman. Sistem memerintahkan GPRS Shield untuk mengirimkan pesan dengan kalimat "Kepekatan Asap mencapai 200 ppm ke atas" menuju nomor ponsel yang telah didaftarkan pada sistem. Jika kepakatan asap belum turun dan bertambah maka nilai yang terbaca oleh sensor MQ-2 juga ikut naik. Jika 
telah mencapai $250 \mathrm{ppm}$ ke atas maka pompa DC masih menyala, alarm juga masih menyala tetapi kali ini GPRS Shield akan melakukan panggilan kepada nomor ponsel tersebut. Ketika kepekatan asap menurun dan berada di bawah 40。C alarm akan dimatikan selain itu sistem memerintahkan relay memutus aliran listrik dari adaptor menuju pompa DC. Jika suhu terdeteksi berada di bawah $40_{\circ} \mathrm{C}$ dan kepekatan asap terdeteksi berada di bawah 200 ppm maka sistem akan mengirim pesan kepada nomor ponsel dengan kalimat "Suhu $<40 * \mathrm{C}$ dan kepekatan asap $<200$ ppm. Kondisi aman". Semua data mengenai gejala kebakaran akan dikirim oleh GPRS ke basis data dalam web.

\subsection{Miniatur Kebun Jambu Biji}

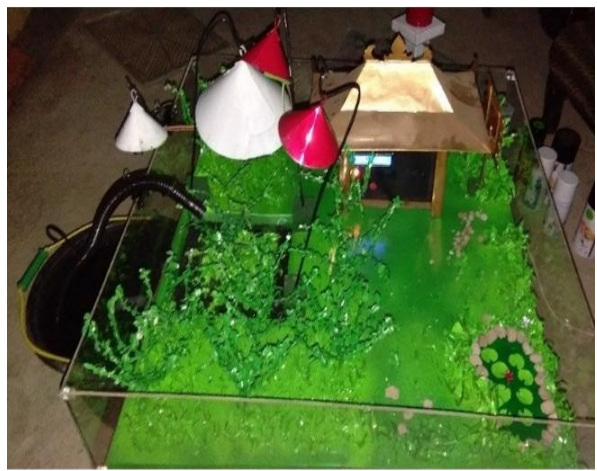

Gambar 3. Tampilan miniatur perkebunan jambu biji.

Tampilan miniatur perkebunan jambu dengan skala 1:20. Alat utama diletakkan pada miniatur rumah. Sensor-sensor seperti LM35, MQ-2, HC-SR04 berada pada cup berbentuk caping agar terhindar dari percikan air. Hal ini menggambarkan melindungi sensor terhadap hujan maupun benda lain yang dapat merusak sensor.
Pompa berada pada ember sebagai tandon penyimpan air. Selang terhubung menuju miniatur pohon jambu biji menggambarkan saat terjadi kebakaran air akan dipancarkan melalui selang untuk menyirami wilayah yang terbakar. Stop kontak berada pada wadah digunakan untuk menghubungkan arus listrik melalui kabel-kabel yang terpasang pada alat utama, pompa air, GPRS Shield dan

\section{Arduino.}

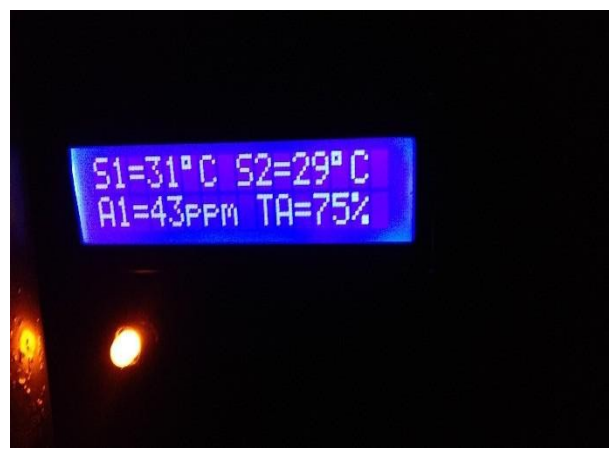

Gambar 4. Alat utama ketika dihidupkan.

Tampilan alat utama. Pada LCD tertera S1 untuk sensor suhu LM35 ke-1, S2 untuk sensor suhu LM35 ke -2, A1 untuk sensor asap MQ-2, TA yang berarti Tinggi Air dari sensor HCSR04.

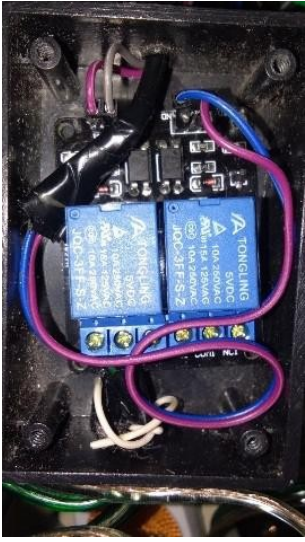

Gambar 5. Tampilan Relay. 
Tampilan relay menggunakan daya dari adaptor 5 Volt DC. Relay yang digunakan adalah Opto

isolated dual relay module. Pin JD-VCC dan GND untuk dihubungkan dengan adaptor 5 VDC. Untuk deretan VCC, IN1 maupun GND untuk dihubungkan dengan Arduino tetapi hanya VCC dan IN1 yang dihubungkan dengan Arduino.

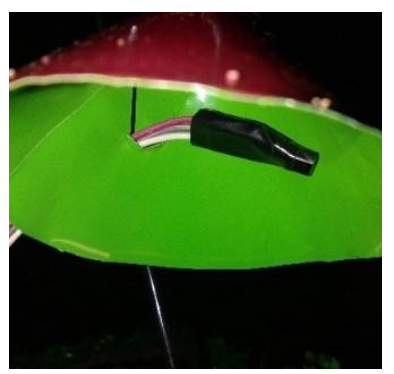

Gambar 6. Sensor suhu LM35.

Tampilan sensor suhu LM35 yang terpasang pada alat. Caping kecil digunakan untuk melindungi sensor dari percikan air.

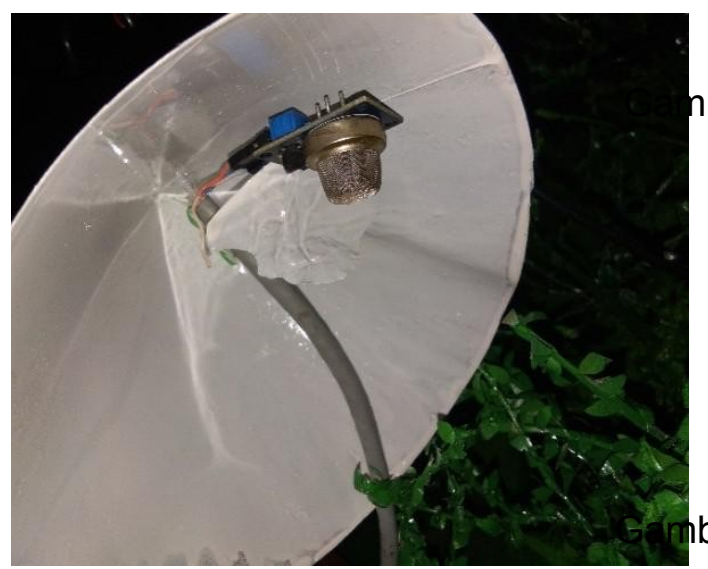

Gambar 7. Sensor asap MQ-2.

Tampilan sensor asap MQ-2 yang terpasang pada alat. Caping kecil digunakan untuk

melindungi sensor dari percikan air.

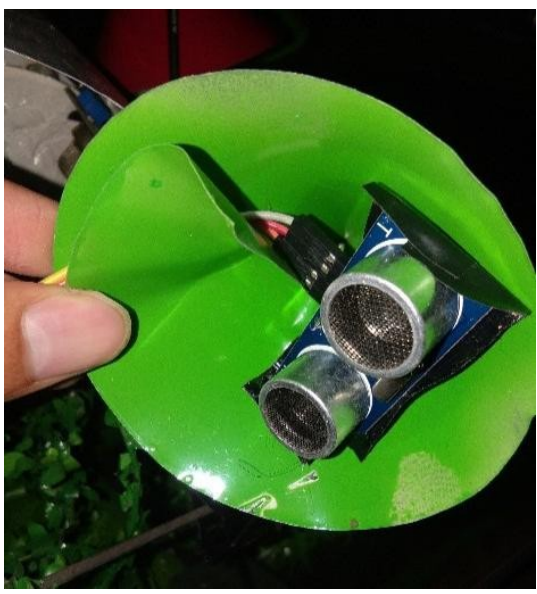

Gambar 8. Sensor Ultrasonik HCSR04.

Tampilan Sensor HC-SR04. Caping kecil digunakan untuk melindungi sensor dari percikan air.

\section{Suhu terdeteksi \\ mencapai $43 * \mathrm{C}$ pada \\ sensor suhu 2}

\section{9:19 2}

bar 9. SMS yang dikirim oleh sistem ke ponsel pengguna.

Suhu terdeteksi

mencapai $44 \_\mathrm{C}$ pada

sensor suhu 1

\section{$12: 05[2$}

bar 10. SMS yang dikirim oleh sistem ke ponsel pengguna.

Saat kepekatan suhu yang terdeteksi LM35 mencapai 
$\geq 40$ 。C dan $<50$ oC sistem mengirim pesan kepada nomor ponsel yang telah didaftarkan pada sistem.

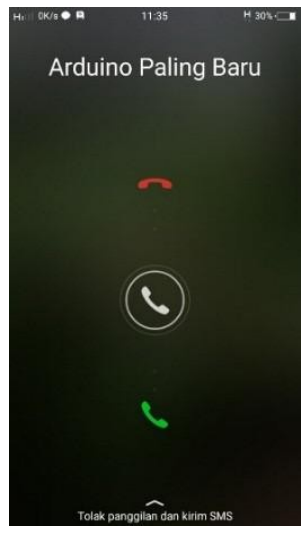

Gambar 11. Tampilan ponsel pengguna saat suhu yang terdeteksi sistem mencapai 50 。C ke atas.

Saat suhu yang terdeteksi sensor LM35 mencapai 50。C ke atas sistem akan memanggil nomor ponsel yang telah didaftarkan pada sistem.

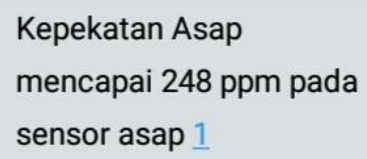

Gambar 12. SMS yang dikirim oleh sistem ke ponsel pengguna.

Saat kepekatan asap yang terdeteksi MQ-2 mencapai $\geq 200 p p m$ dan <250 ppm sistem mengirim pesan kepada nomor ponsel yang telah didaftarkan pada sistem.

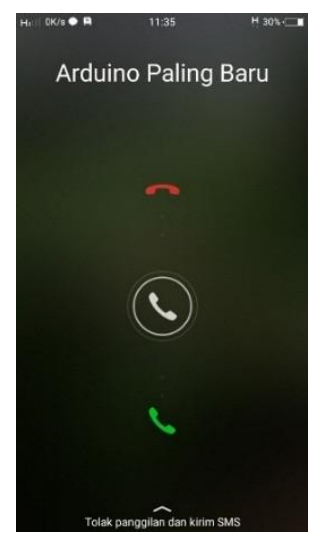

Gambar 13. Tampilan ponsel pengguna dengan sistem operasi Androidsaat kepekatan asap yang terdeteksi sistem mencapai 250 ppm ke atas.

Saat kepekatan asap yang terdeteksi sensor MQ-2 mencapai $250 \mathrm{ppm}$ ke atas sistem akan memanggil nomor ponsel yang telah didaftarkan pada sistem.

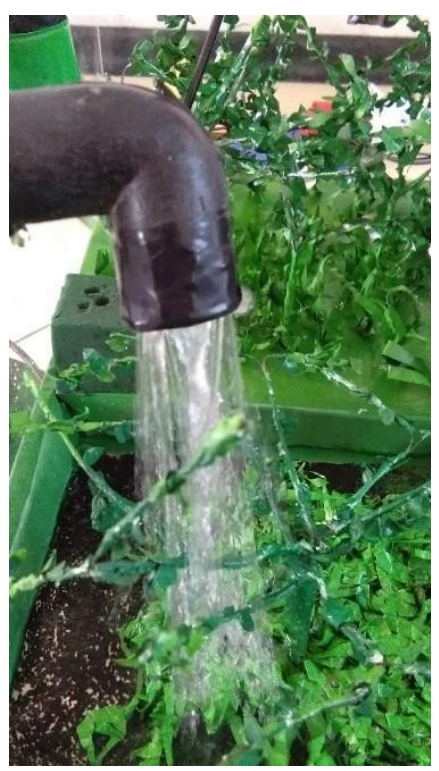

Gambar 14. Saat relay dalam keadaan ON pompa mengalirkan air.

Ketika suhu yang terdeteksi LM35 mencapai 
$\geq 40$ 。C dan atau saat kepekatan asap yang terdeteksi MQ -2 mencapai $\geq 200 p p m$ relay yang menjadi saklar berstatus ON dan pompa mengalirkan air melewati selang menuju miniatur kebun.

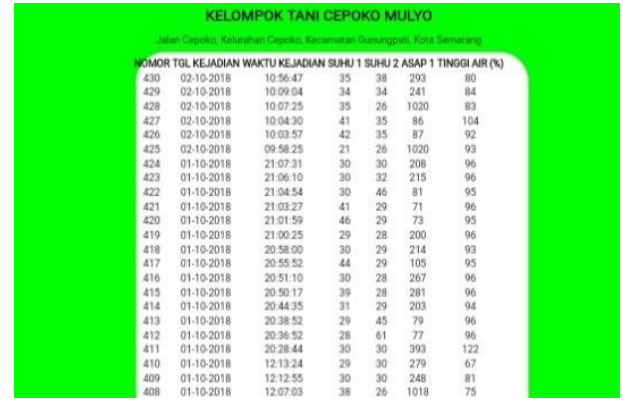

Gambar 15. Rekaman runtutan kejadian kebakaran yang telah dikirm ke basis data web.

$$
\text { Runtutan kejadian }
$$
kebakaran yang telah terdeteksi oleh sensor LM35 dan MQ- 2 maka secara otomatis akan dikirm menuju basis data web pada alamat pantaukebun.atwebpages.co $\mathrm{m}$.

Air berada $15 \%$ ke bawah, mohon diisi kembali

Gambar 16. SMS yang dikirim oleh sistem ke ponsel pengguna.

Saat volume air dalam tandon penampung air sebanyak $15 \%$ ke bawah maka sistem mengirim pesan kepada nomor ponsel yang telah didaftarkan pada sistem.

\subsection{Pengujian Sistem Secara Keseluruhan}

Pengujian ini dilakukan untuk menjalankan sistem secara keseluruhan dan mengetahui apakah sistem dapat berjalan sesuai dengan yang diharapkan. Berikut adalah tabel pengujian sistem secara keseluruhan.

Tabel 1. Pengujian Sistem Secara Keseluruhan

\begin{tabular}{|c|c|c|c|c|c|}
\hline \multirow{2}{*}{ Alat } & \multicolumn{5}{|c|}{ Pengujian Ke- } \\
\hline & 1 & 2 & 3 & 4 & 5 \\
\hline LM35 ke-1 $\left({ }^{\circ} \mathrm{C}\right)$ & 29 & 31 & 39 & 44 & 30 \\
\hline LMB $55 \mathrm{ke}-2\left({ }^{\circ} \mathrm{C}\right)$ & 45 & 29 & 28 & 29 & 29 \\
\hline $\mathrm{MQ}-2(\mathrm{ppm})$ & 79 & 203 & 281 & 105 & 214 \\
\hline Waktu Terdeteksi (deikik) & 02,83 & 02,54 & 14,68 & 03,82 & 03,10 \\
\hline HC-SR04/ & 96 & 94 & 96 & 95 & 93 \\
\hline $\begin{array}{l}\text { Volume Air (\%) } \\
\text { LCD }\end{array}$ & Terbaca & Terbaca & Terbaca & Terbaca & Terbaca \\
\hline Alarm & v & $\sqrt{ }$ & $\sqrt{ }$ & v & v \\
\hline Relay & $\checkmark$ & v & $\sqrt{ }$ & $\sqrt{ }$ & v \\
\hline SMS Gateway & $\sqrt{ }$ & $v$ & $\sqrt{ }$ & $\checkmark$ & 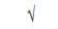 \\
\hline Telephony Gateway & . & 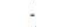 & $\checkmark$ & - & - \\
\hline Basis Data Web & $\checkmark$ & $\sqrt{ }$ & $\sqrt{ }$ & $\sqrt{ }$ & $\checkmark$ \\
\hline
\end{tabular}

Keterangan :

a. LM35 ke-1 menggunakan satuan derajat Celcius $\left({ }^{\circ} \mathrm{C}\right)$.

b. LM35 ke-2 menggunakan satuan derajat Celcius $\left({ }^{\circ} \mathrm{C}\right)$.

c. MQ-2 menggunakan satuan ppm (part-per million).

d. Waktu Terdeteksi menggunakan satuan detik.

e. HC-SR04 / Volume Air menggunakan satuan persen (\%).

\section{Tabel 2. Pengujian Sistem}

Secara Keseluruhan 


\begin{tabular}{cccccc}
\hline \multirow{2}{*}{ Alat } & \multicolumn{5}{c}{ Pengujaan Ke- } \\
\cline { 2 - 6 } & 6 & 7 & 8 & 9 & 10 \\
\hline LM35 ke-1 ( $\left.{ }^{\circ} \mathrm{C}\right)$ & 29 & 46 & 41 & 30 & 30 \\
LM35 ke-2( $\left.{ }^{\circ} \mathrm{C}\right)$ & 28 & 29 & 29 & 46 & 30 \\
MQ-2(ppm) & 200 & 73 & 71 & 81 & 208 \\
Waktu Terdeteksi (detik) & 02,47 & 08,92 & 04,37 & 03,69 & 04,18 \\
HC-SR04/ & 96 & 95 & 96 & 95 & 96 \\
Volume Air (\%) & Terbaca & Terbaca & Terbaca & Terbaca & Terbaca \\
LCD & $\sqrt{ }$ & $\sqrt{ }$ & $\sqrt{ }$ & $\sqrt{ }$ & $\sqrt{ }$ \\
Alarm & $\sqrt{ }$ & $\sqrt{ }$ & $\sqrt{ }$ & $\sqrt{ }$ & $\sqrt{ }$ \\
Relay & $\sqrt{ }$ & $\sqrt{ }$ & $\sqrt{ }$ & $\sqrt{ }$ & $\sqrt{ }$ \\
SMS Gateway & - & - & - & - & - \\
Telephony Gateway & - & $\sqrt{ }$ & $\sqrt{ }$ & $\sqrt{ }$ & $\sqrt{ }$ \\
Basis Data Web & $\sqrt{ }$ & & & &
\end{tabular}

Keterangan :

a. LM35

ke-1

menggunakan satuan derajat Celcius $\left({ }^{\circ} \mathrm{C}\right)$.

b. LM35 ke-2 menggunakan satuan derajat Celcius $\left({ }^{\circ} \mathrm{C}\right)$.

c. MQ-2 menggunakan satuan ppm (part-per million).

d. Waktu menggunakan satuan detik.

e. HC-SR04 / Volume Air menggunakan satuan persen (\%).

Berdasarkan hasil pengujian sistem secara keseluruhan pada Tabel 1 dan Tabel 2 menunjukkan bahwa ketika sensor suhu LM35ke1 dan/atau sensor suhu LM35 ke-2 mendeteksi suhu telah mencapai 40 。C hingga kurang dari $50^{\circ} \mathrm{C}$ alarm berbunyi, relay aktif, SMS Gateway terkirim dan tercatat dalam basis data web. Ketika sensor asap MQ-2 mendeteksi angka mencapai 200 ppm hingga di bawah 250 ppm alarm berbunyi, relay aktif, SMS Gateway terkirim dan tercatat dalam basis data web dan ketika mencapai $250 \mathrm{ppm}$ ke atas maka sistem akan melakukan panggilan kepada nomor perangkat handphone

pengguna yang telah didaftarkan pada sistem, ini dinamakan Telephony Gateway. Rata-rata waktu terdeteksi sensor mencapai angka yang ditentukan untuk masing-masing sensor sebagai berikut:

$$
\begin{aligned}
& \frac{02,83+02,54+14,68+03,82+03,10+02,47+08,92+04,37+03,69+04,18}{10}= \\
& =\frac{50,60}{10}=5,06 \text { detik }
\end{aligned}
$$

Hal ini menunjukkan bahwa sistem dapat digunakan dengan baik untuk memenuhi kebutuhan sistem pencegah kebakaran pada perkebunan jambu biji.

\section{KESIMPULAN}

Berdasarkan hasil penelitian dan pembahasan mengenai produk sistem pencegah kebakaran pada perkebunan jambu biji menggunakan sensor suhu LM35 dan SMS Gateway berbasis Arduino Uno, maka diperoleh hasil sebagai berikut:

a. Sistem dapat mengetahui dengan mudah titik terjadinya kebakaran. Hal ini dapat dibuktikan dengan jelas dari tabel 4.7 dan tabel 4.8 bagian mana saja sensor suhu LM35 ke-1 dan sensor suhu LM35 ke-2 dengan angka mencapai $40_{0} \mathrm{C}$ ke atas dan sensor asap MQ-2 dengan angka mencapai $200 \mathrm{ppm}$ ke atas. Masing-masing sensor diletakkan di tempat yang berbeda, dengan demikian letak terjadinya kebakaran mudah diketahui.

b. Sistem dapat mengetahui tingkat volume air dalam tandon dengan mudah. Hal ini dapat dibuktikan pada tabel 4.7 dan tabel 4.8 pada baris HC-SR04 / Volume Air

(\%). Tingkat volume air dinyatakan dalam satuan persen $(\%)$.

c. Sistem dapat mengirim rekaman runtutan kejadian kebakaran secara otomatis dan lengkap ke 
basis data web. Hal ini dapat dibuktikan pada gambar 4.16, sistem mengirim secara lengkap tanggal kejadian, waktu kejadian, masing-masing angka yang tertera pada sensor suhu LM35 ke-1 (suhu 1), sensor suhu LM35 ke-2 (suhu 2), sensor asap MQ-2 (asap 1) dan sensor ultrasonik HC-SR04 (tinggi air).

\section{DAFTAR PUSTAKA}

[1] Andriani, Anizar. 2014. Pemanfaatan Sensor Suhu LM35 Berbasis ATMega Pada Sistem Pengontrolan Temperatue Air Laut Skala Kecil. Bengkulu: Universitas Bengkulu.

[2] Apryandi, Subhan. 2013. Rancang Bangun Sistem Detektor Kebakaran Via Handphone Berbasis Mikrokontroler. Pontianak: Tugas Akhir Program Studi Teknik Elektro Fakultas Teknik Universitas Tanjungpura.

[3] Hakim, Abrar, Cyntia Widiasari dan M. Yanuar Hariyawan. Tanpa Tahun. Pengukur Kelembaban Tanah dan Suhu Udara sebagai Pendeteksi Dini Kebakaran Hutan melalui Wireless Sensor Network (WSN) Hardware. Pekanbaru: Jurusan Teknik Elektro Politeknik Caltex Riau.

[4] Harsono, Djiwo, Joko Sunardi dan Desi Biantara. 2009. Pemantauan Suhu dengan Mikrokontroler Atmega8 pada Jaringan Lokal. Seminar Nasional V Sdm Teknologi Nuklir Yogyakarta, 5 NOVEMBER 2009 ISSN 1978-0176. Yogyakarta: Sekolah Tinggi Teknologi Nuklir BATAN.

[5] Kristianto, Eko.2013. Monitoring Suhu Jarak Jauh Generator AC Berbasis Mikrokontroler. Yogyakarta: Tugas Akhir Jurusan Pendidikan Teknik Elektro Fakultas Teknik Universitas Negeri Yogyakarta.

[6] Lapanporo, Boni Pahlanop. 2011. Prototipe Sistem Telemetri Berbasis Sensor Suhu dan Sensor Asap untuk Pemantau Kebakaran Lahan. ISSN:
2301-4970, Positron Vol. I, No. 1

(2011), Hal. 43-49. Pontianak: Program Studi Fisika, FMIPA

Universitas Tanjungpura.

[7] Pamungkas, Bimo Ananto, Adian Fatchur Rochim dan Eko Didik Widianto. Tanpa Tahun. Perancangan Jaringan Sensor Terdistribusi untuk Pengaturan Suhu, Kelembaban, dan Intensitas Cahaya. Semarang: Tugas Akhir Program Studi Sistem Komputer Fakultas Teknik Universitas Diponegoro.

[8] Sadjad, Rhiza S., Andani Ahmad, Indrabayu, Zaenab Muslimin, Fitriyanti Mayasari dan Rahmat Syaifullah. 2014.Kebencanaan dan Lingkungan; Modifikasi Sistem Sensor dan Struktur Prototype Robot Pendeteksi Api untuk Deteksi Dini AncamanKebakaran. Makassar: Laporan Akhir Kompetisi Internal Program Studi. Universitas Hasanuddin. 